\title{
Fish welfare and biological rhythms: time to regulate
}

\author{
$\mathrm{F}^{\mathrm{o}}$ Javier Sánchez-Vázquez, José Fernando López-Olmeda, Luisa María Vera \\ Dep. Physiology. Fac. Biology. Murcia University. Spain
}

Received: October 2019

Accepted: October 2019

Recommended citation. SÁNCHEZ-VÁZQUEZ, F.J., LÓPEZ-OLMEDA, J.F., VERA, L.M., Fish welfare and biological rhythms: time to regulate, dA. Derecho Animal (Forum of Animal Law Studies) 10/4 (2019) - DOI https://doi.org/10.5565/rev/da.461

\begin{abstract}
In this article we introduce the concept of biological rhythms in fish welfare and critically discuss a neglected aspect: time-dependent issues. First we should consider that fish, like most living organisms, posses a clock that drives rhythmic biological functions. Therefore, fish stress responses are strongly affected by the time of stressor exposure (e.g. day/night) according to their daily pattern of behavior (diurnal/nocturnal). Furthermore, drugs affect fish differently depending of time of administration. For instance, commonly used substances such as anesthetics may have strikingly different effects depending on the time of day. MS-222 -the most widely used fish anesthetics- has fastest effects and higher toxicity when applied during daytime, but it is much less toxic at night. Surprisingly, no attention has been paid to this time-dependent factor when establishing dosages and protocols for fish anesthesia and euthanasia. In summary, there is a need to take into account properly the role of biological rhythms when discussing fish welfare issues and regulations by the Institutional Animal Care and Use Committee (IACUC).
\end{abstract}

Key words: chronobiology, biological clocks, stress indicators, chronotoxicity, anesthetics..

Resumen - Bienestar de peces y ritmos biológicos: tiempo para regular

En este artículo se introduce el concepto de ritmos biológicos en el bienestar de peces, y se discute críticamente un tema olvidado: aspectos dependientes del tiempo. Primero debemos considerar que los peces, al igual que la mayoría de organismos vivos, poseen un reloj interno que dirige los ritmos biológicos. Por tanto, las respuestas al estrés de los peces están fuertemente afectadas por la hora de exposición al agente estresante (p.e. día/noche) en función de su patrón diario de comportamiento (diurno/nocturno). Además, los fármacos pueden afectar de forma diferente a los peces dependiendo de la hora de la administración. Por ejemplo, sustancias comúnmente usadas como los anestésicos pueden tener efectos llamativamente distintos dependiendo de la hora del día. El MS-222, el anestésico más ampliamente utilizado en peces, tiene efectos más rápidos y mayor toxicidad cuando es aplicado por el día, pero es mucho menos tóxico por la noche. Sorprendentemente, no se ha prestado atención a este factor temporal cuando se establecen dosis y protocolos para la anestesia o eutanasia de peces. En resumen, es necesario tener en cuenta adecuadamente el papel de los ritmos biológicos cuando se discute el bienestar de peces y su regulación por los comités de uso y cuidado de animales.

Palabras clave: cronobiología, relojes biológicos, indicadores de estrés, cronotoxicidad, anestésicos. 


\section{Fish clocks}

Classic definitions of homeostasis brought about the idea of keeping steady internal conditions (e.g. body temperature, plasma metabolites, hormones, etc), within certain pre-set limits, for the optimal functioning of living organisms. Most physiological variables, however, do not show constant, rigid values, but a dynamic state of equilibrium with periodic oscillations (i.e. rhythms). Actually, homeostatic and circadian processes are tightly interconnected, so that circadian disruptions lead to welfare impairment and pathological affections ${ }^{1}$.

Biological rhythms are driven by internal clocks that keep time and provide the organisms with the capacity of anticipating periodic events (e.g. sunrise/sunset, tides, moon phases or seasons). Biological clocks are ubiquitous and of enormous adaptive value as they allow the organism to time internal physiological events in order to cope with forthcoming, potentially harmful events, such as exposure to extreme temperatures, food deprivation, predation risk, etc ${ }^{2}$. Fish, like most animals, display biological rhythms driven by an internal time-keeping mechanism that relay on molecular loops of expression of clock genes, which persist under constant conditions in the absence of environmental cues ${ }^{3}$. Key behavioural and physiological functions such as feeding and reproduction in fish, do not occur at random, but they are timed according to maximum food availability and offspring survival. The light/dark cycle is the most powerful environmental synchronizer (or zeitbeger), and it is transduced by the pineal organ into the rhythmic secretion of the hormone melatonin. In addition, feeding cycles can act as a potent zeitgeber driving behavioural and physiological responses in fish ${ }^{4}$.

\section{Stress responses differ depending on time}

Since the physiological systems of fish present differences depending on time, it should not be surprising that they respond differently to a given stressor depending on the time of exposure. Actually, in fish, the hypothalamus-pituitary-interrenal (HPI) axis, which is also called the "stress axis" which controls the primary stress responses, is under circadian regulation. Therefore, stress indicators such as corticotropinreleasing hormone and its binding protein, proopiomelanocortin A and $\mathrm{B}$, plasma cortisol, glucose and lactate, all exhibit daily rhythms. Moreover, melatonin (the dark-signaling hormone, released at night) interplays in stress responses, mitigating adverse effects in fish through both central and peripheral actions ${ }^{5}$. Therefore, the response to an acute stressor may depend on the time of the day when the stress occurs. For instance, in Senegalese sole, a nocturnal species, fish showed higher cortisol levels when exposed to air for 30 seconds during day time, whereas at night their response was milder ${ }^{6}$. However, in gilthead sea bream, a diurnal fish, air exposure for 30 seconds produced higher cortisol levels when fish were stressed at night ${ }^{7}$.

In summary, stress responses not only depend on fish species, but also on the time-of-day of the acute exposure to the stressor. As the stress response presents daily rhythms, we could expect that a stressful situation (e.g. fish manipulation, transport, grading, vaccination, etc) would have a different impact on fish welfare depending on the time of day in which it is performed. We cannot generalize and so we must count on the daily behavioural patterns of fish. It appears that fish are prone to suffer severe stress during their resting phase, whereas they are more resistant to stress when they are active.

\footnotetext{
${ }^{1}$ GNOCCHI, D., BRUSCALUPI, G., Circadian Rhythms and Hormonal Homeostasis: Pathophysiological Implications. Biology (Basel) 6/1 (2017) 10; DOI: 10.3390/biology6010010

${ }^{2}$ SHARMA, V.K., Adaptive Significance of Circadian Clocks. Chronobiol. Int. 20/6 (2003) 901-919.

${ }^{3}$ STEINDAL, F., WHITMORE, D., Circadian Clocks in Fish-What Have We Learned so far? Biology (Basel) 19; 8/1 (2019); DOI: 10.3390/biology8010017

${ }^{4}$ KULCZYKOWSKA, E., POPEK, W., KAPOOR, B.G., Biological clock in fish. CRC Press -Taylor \& Francis Group (2010); ISBN 9780367383954

${ }^{5}$ SÁNCHEZ-VÁZQUEZ, F.J., LÓPEZ-OLMEDA, J.F., VERA, L.M., MIGAUD, H., LÓPEZ-PATIÑO, M.A., MIGUEZ, J.M., Environmental Cycles, Melatonin, and Circadian Control of Stress Response in Fish. Front. Endocrinol (2019) 11; DOI: 10.3389/fendo.2019.00279.

${ }^{6}$ LÓPEZ-OLMEDA, J.F., BLANCO-VIVES, B., PUJANTE, I.M., WUNDERIK, Y.S., MANCERA, J.M., SÁNCHEZ-VÁZQUEZ, F.J., Daily rhythms in the hypothalamus-pituitary-interrenal axis and acute stress responses in a teleost flatfish, Solea senegalensis. Chronobiol. Int. 30/4 (2013) 530-539; DOI: 10.3109/07420528.2012.754448

7 VERA, L.M., MONTOYA, A., PUJANTE, I.M., PÉREZ-SÁNCHEZ, J., CALDUCH-GINER, J.A., MANCERA, J.M., MOLINER, J., SÁNCHEZ-VÁZQUEZ, F.J., Acute stress response in gilthead sea bream (Sparus aurata L.) is time-of-day dependent: Physiological and oxidative stress indicators. Chronobiol. Int. 312 (2010) 1051-1061; DOI:
} $10.3109 / 07420528.2014 .945646$

94 Derecho Animal. Forum of Animal Law Studies, vol. 10/4 


\section{Chronotoxicity and anesthetics}

Fish anesthetics have been extensively used over 100 years in millions of fish both in research labs and aquaculture farms. Effective and lethal doses have been classically established according to fish size, water quality, oxygen levels, $\mathrm{pH}$, salinity, etc ${ }^{8,9}$. However, the use of anesthetics in fish is far more complicated than expected, as behavioural responses against anesthetics may differ depending on fish species ${ }^{10}$. Despite extensive investigations on the physiology, dosage and precautions of anesthetics, the time-effects were neglected.

In the case of the commonly used anesthetic tricaine methasulphonate (MS-222), for fish anesthesia and euthanasia a dosis of 50 and $250 \mathrm{mg} / \mathrm{L}$, respectively, is recommended by official guidelines ${ }^{11}$, although nothing is said about timing of exposure despite the great variability found in the literature ${ }^{12}$. In zebrafish, the median lethal (LC50) decreased with age (3-9 dpf) and duration of exposure (1-24h) ${ }^{13}$. A pioneer paper in this species reported strikingly different effects depending on the time of the day: the acute toxicity (LC50) caused by MS-222 was $171 \mathrm{mg} / \mathrm{L}$ when fish were exposed for 15 min during the day, and $216 \mathrm{mg} / \mathrm{L}$ when exposed at night ${ }^{14}$ (Table 1). Similar results were found when using sublethal concentrations (60 $\mathrm{mg} / \mathrm{L}$ ), with higher effectiveness during the day and longer times to induce anesthesia at night. In zebrafish, eugenol (clove oil) also had higher effectiveness and toxicity during daytime (LC50 $=70 \mathrm{mg} / \mathrm{L}$ during the day and $105 \mathrm{mg} / \mathrm{L}$ at night). In gilthead sea bream, the induction time of MS-222 and subsequent recovery, differed between day and night, with shorter induction and longer recovery during the day. The toxicity of MS-222 was also higher during the day $(\mathrm{LC} 50=86 \mathrm{mg} / \mathrm{L})$ than at night $(\mathrm{LC} 50=108 \mathrm{mg} / \mathrm{L})^{15}$ (Table 1$)$. In this species, the chronotoxicity of MS-222 appeared to be related to daily rhythms in detoxification mechanisms (hepatic glutation-S-transferase) and plasma MS-222 concentrations, which were higher during the day than at night $(142 \mathrm{ng} / \mathrm{ml} v s 96 \mathrm{ng} / \mathrm{ml} \text {, respectively })^{16}$. Moreover, in this species the toxicity rhythm of MS-222 could be phase-shifted by feeding schedule, so that the effectiveness of the anesthetic at night became higher in fish fed at mid-night, than in those fed at mid-day.

\section{$\mathrm{LC}_{50}(\mathrm{mg} / \mathrm{mL})$}

\begin{tabular}{llll}
\cline { 3 - 4 } & & ML & MD \\
\hline \multirow{2}{*}{ Zebrafish (Danio rerio) } & MS-222 & $170.5 \pm 7.4$ & $213.6 \pm 3.9$ \\
\cline { 2 - 4 } & Eugenol & $70.3 \pm 3.1$ & $104.9 \pm 5.4$ \\
\hline Gilthead sea bream (Sparus auratus) & MS-222 & $85.5 \pm 1.5$ & $107.6 \pm 2.7$ \\
\hline
\end{tabular}

Table 1. MS-222 and eugenol concentrations $(\mathrm{mg} / \mathrm{mL})$ corresponding to the LC50 in zebrafish and gilthead sea bream exposed to the anaesthetics in the middle of the light phase (ML) or in the middle of the dark phase (MD) (from Sánchez-Vázquez et al. 2010, and Vera et al. 2010).

\footnotetext{
${ }^{8}$ ACKERMAN, P.A., MORGAN, J.D., IWAMA, G.K., Anesthetics. CCAC guidelines on: the care and use of fish in research, teaching and testing (2005); http://www.ccac.ca/en/CCAC_Programs/Guidelines_Policies/GDLINES/Fish/Fish

${ }^{9}$ ZAHL, I.H., SAMUELSEN, O., KIESSLING, A., Anaesthesia of farmed fish: implications for welfare. Fish Physiol. Biochem. 38 (2012) 201-218; DOI: 10.1007/s10695-011-9565-1

${ }^{10}$ READMAN, G.D., OWEN, S.F., KNOWLES, T.G., MURREL, J.C., Species specific anaesthetics for fish anaesthesia and euthanasia. Scientific Reports, 7 (2017) 7102; DOI: 10.1038/s41598-017-06917-2

${ }^{11}$ AVMA, American Veterinary and Medical Association guidelines on euthanasia (2007); https://olaw.nih.gov/sites/default/files/Euthanasia2007.pdf

12 POPOVIC, N.T., STRUJAK-PEROVIC, I., COZ-RAKOVAC, R., BARISIC, J., JADAN, M., BERAKOVIC, A.P., KLOBUCAR, R.S., Tricaine methane-sulfonate (MS-222) application in fish anaesthesia. J. Appl. Ichthyol. 28 (2012) 553-564; DOI: 10.1111/j.1439-0426.2012.01950.x

${ }^{13}$ ROMBOUGH, P.J., Ontogenetic changes in the toxicity and efficacy of the anaesthetic MS222 (tricaine methanesulfonate) in zebrafish (Danio rerio) larvae. Comp. Biochem. Physiol. A. 148 (2007) 463-469; DOI: 10.1016/j.cbpa.2007.06.415

${ }^{14}$ SÁNCHEZ-VÁZQUEZ, F.J., TERRY, M., FELIZARDO, V.O., VERA, L.M., Daily Rhythms of Toxicity and Effectiveness of Anesthetics (MS222 and Eugenol) in Zebrafish ( Danio Rerio). Chronobiol. Int. 28 (2011) 109-117; DOI: 10.3109/07420528.2010.538105

${ }^{15}$ VERA, L.M., ROS-SÁNCHEZ, G., GARCÍA-MATEOS, G., SÁNCHEZ-VÁZQUEZ, F.J., MS-222 toxicity in juvenile seabream correlates with diurnal activity, as measured by a novel video-tracking method. Aquaculture, 307 (2010) 29-34; DOI: 10.1016/j. aquaculture.2010.06.028

${ }^{16}$ VERA, L.M., MONTOYA, A., SÁNCHEZ-VÁZQUEZ, F.J., Effectiveness of the anaesthetic MS-222 in gilthead seabream, Sparus aurata: effect of feeding time and day-night variations in plasma MS-222 concentration and GST activity. Physiol Behav. 110-111 (2003) 51-7. DOI: 10.1016/j.physbeh.2012.12.012.
} 


\section{Time-dependent regulations}

In the last few years, efforts have been made to integrate chronobiology with medical and veterinary science to give proper consideration to biological rhythms when assessing the welfare of animals and human beings ${ }^{17}$. There is a need to better understand the temporal organization of the animals' physiology and their interactions with environmental cycles. In terrestrial animals, special attention has been paid to illumination and environmental enrichment (e.g. controlled photoperiod, hiding places) to prevent chronodisruptions and sleep disorders. In fish, there is still a lack of practical knowledge on how biological rhythms affect welfare, so that standard procedures could be specified in guidelines for the care and use of animals. But, it is clear that timing should be considered as a key factor when establishing protocols by the Institutional Animal Care and Use Committee (IACUC) when making regulations and directives.

\section{Conclusions}

Research on biological rhythms has provided evidence for the importance of considering time when discussing animal welfare. As reviewed, the HPI axis as well as stress indicators show daily rhythms, which in turn make fish more stressful at certain times of the day/night. Drugs may also have different effects depending on the time of administration. Time-effects should be considered in the future by the IACUC to produce standard practices and guidelines that safeguard fish welfare.

\section{References}

- ACKERMAN, P.A., MORGAN, J.D., IWAMA, G.K., Anesthetics. CCAC guidelines on: the care and use of fish in research, teaching and testing (2005); http://www.ccac.ca/en/CCAC_ Programs/Guidelines_Policies/GDLINES/Fish/Fish

- AVMA, American Veterinary and Medical Association guidelines on euthanasia (2007). https://olaw.nih.gov/sites/default/files/Euthanasia2007.pdf

- BITTMAN, E.L., KILDUFF, T.S., KRIEGSFELD, L.J., SZYMUSIAK, R., TOTH, L.A., TUREK, F.W., Animal Care Practices in Experiments on Biological Rhythms and Sleep: Report of the Joint Task Force of the Society for Research on Biological Rhythms and the Sleep Research Society. J. Am. Assoc. Lab Anim. Sci. 52 (2013) 437-443.

- GNOCCHI, D., BRUSCALUPI, G., Circadian Rhythms and Hormonal Homeostasis: Pathophysiological Implications. Biology (Basel) 6/1 (2017) 10; DOI: 10.3390/biology6010010

- KULCZYKOWSKA, E., POPEK, W., KAPOOR, B.G., Biological clock in fish. CRC Press Taylor \& Francis Group (2010); ISBN 9780367383954

- LÓPEZ-OLMEDA, J.F., BLANCO-VIVES, B., PUJANTE, I.M., WUNDERIK, Y.S., MANCERA, J.M., SÁNCHEZ-VÁZQUEZ, F,J, Daily rhythms in the hypothalamus-pituitaryinterrenal axis and acute stress responses in a teleost flatfish, Solea senegalensis. Chronobiol. Int. 30/4 (2013): 530-539; DOI: 10.3109/07420528.2012.754448

- POPOVIC, N.T., STRUJAK-PEROVIC, I., COZ-RAKOVAC, R., BARISIC, J., JADAN, M., BERAKOVIC, A.P., KLOBUCAR, R.S., Tricaine methane-sulfonate (MS-222) application in fish anaesthesia. J. Appl. Ichthyol. 28 (2012) 553-564; DOI: 10.1111/j.1439-0426.2012.01950.x

- READMAN, G.D., OWEN, S.F., KNOWLES, T.G., MURREL, J.C., Species specific anaesthetics for fish anaesthesia and euthanasia. Scientific Reports, 7 (2017) 7102; DOI: 10.1038/s41598-01706917-2

- ROMBOUGH, P.J., Ontogenetic changes in the toxicity and efficacy of the anaesthetic MS222 (tricaine methanesulfonate) in zebrafish (Danio rerio) larvae. Comp. Biochem. Physiol. A. 148 (2007) 463-469; DOI: 10.1016/j.cbpa.2007.06.415

- SÁNCHEZ-VÁZQUEZ, F.J., LÓPEZ-OLMEDA, J.F., VERA, L.M., MIGAUD, H., LÓPEZPATIÑO, M.A., MIGUEZ, J.M., Environmental Cycles, Melatonin, and Circadian Control of Stress Response in Fish. Front. Endocrinol (2019) 11; DOI: 10.3389/fendo.2019.00279.

- SÁNCHEZ-VÁZQUEZ, F.J., TERRY, M., FELIZARDO, V.O., VERA, L.M., Daily Rhythms of Toxicity and Effectiveness of Anesthetics (MS222 and Eugenol) in Zebrafish ( Danio Rerio).

\footnotetext{
${ }^{17}$ BITTMAN, E.L., KILDUFF, T.S., KRIEGSFELD, L.J., SZYMUSIAK, R., TOTH, L.A., TUREK, F.W., Animal Care Practices in Experiments on Biological Rhythms and Sleep: Report of the Joint Task Force of the Society for Research on Biological Rhythms and the Sleep Research Society. J. Am. Assoc. Lab Anim. Sci. 52 (2013) 437-443.

96 Derecho Animal. Forum of Animal Law Studies, vol. 10/4
} 
Chronobiol. Int. 28 (2011) 109-117; DOI: 10.3109/07420528.2010.538105

- SHARMA, V.K., Adaptive Significance of Circadian Clocks. Chronobiol. Int. 20/6 (2003) 901919

- STEINDAL, F., WHITMORE, D., Circadian Clocks in Fish-What Have We Learned so far? Biology (Basel) 19; 8/1 (2019); DOI: 10.3390/biology8010017

- VERA, L.M., MONTOYA, A., PUJANTE, I.M., PÉREZ-SÁNCHEZ, J., CALDUCH-GINER, J.A., MANCERA, J.M., MOLINER, J., SÁNCHEZ-VÁZQUEZ, F.J., Acute stress response in gilthead sea bream (Sparus aurata L.) is time-of-day dependent: Physiological and oxidative stress indicators. Chronobiol. Int. 312 (2010) 1051-1061; DOI: 10.3109/07420528.2014.945646

- VERA, L.M., MONTOYA, A., SÁNCHEZ-VÁZQUEZ, F.J., Effectiveness of the anaesthetic MS222 in gilthead seabream, Sparus aurata: effect of feeding time and day-night variations in plasma MS-222 concentration and GST activity. Physiol Behav. 110-111 (2003) 51-7. DOI: 10.1016/j.physbeh.2012.12.012

- VERA, L.M., ROS-SÁNCHEZ, G., GARCÍA-MATEOS, G., SÁNCHEZ-VÁZQUEZ, F.J., MS222 toxicity in juvenile seabream correlates with diurnal activity, as measured by a novel videotracking method. Aquaculture, 307 (2010) 29-34; DOI: 10.1016/j.aquaculture.2010.06.028

- ZAHL, I.H., SAMUELSEN, O., KIESSLING, A., Anaesthesia of farmed fish: implications for welfare. Fish Physiol. Biochem. 38 (2012) 201-218; DOI: 10.1007/s10695-011-9565-1 